\title{
IMÁGENES MÍTICAS Y ONÍRICAS: UN ANÁLISIS DESDE LA PSICOLOGÍA ARQUETIPAL
}

\section{MYTICHAL AND ONIRIC IMAGES: AN ANALYSIS FROM ARCHETYPAL PSYCHOLOGY}

\author{
José Francisco da Silva Filho ${ }^{1}$
}

ORCID: https://orcid.org/0000-0002-5817-1043

\begin{abstract}
Resumen: Para desarrollar este artículo nos respaldamos en la psicología arquetipal y, fundamentalmente, en las obras de James Hillman, su principal representante. Nuestro objetivo con este trabajo es reexaminar su pensamiento y revisar en sus textos las ideas fundamentales que giran alrededor de las imágenes míticas y oníricas, las cuales representan un distanciamiento de los estrechos modelos racionales y tradicionales aún vigentes. Elegimos a priori algunas direcciones teóricas de la mitopoética para orientar esa investigación sobre las imágenes, así que vamos a dar énfasis también a autores como Mircea Eliade, Ernst Cassirer y Gaston Bachelard que abordan este tema desde una perspectiva más mítico-simbólica.
\end{abstract}

Palabras-llave: Psicología arquetipal. Imágenes míticas. Imágenes oníricas.

\begin{abstract}
To develop this article we rely on archetypal psychology and, fundamentally, on the words of James Hillman, its main representat. Our objective with this Work is to reexamine his thinking and review in his texts the fundamental ideas that revolve around mythical and dream imagens, which represent a distancing from the narrow rational and tradicional models still present. We chose a priori some theoretical directions of mythopoetics to guide this research on images, so we will also give emphasis to authors such as Mircea Eliade, Ernst Cassirer and Gaston Bachelard who approach this topic from a more mythical-symbolic perspective.
\end{abstract}

Keywords: Archetypal psychology. Mythical images. Dream images.

\footnotetext{
${ }^{1}$ Possui graduação em Letras pela Universidade Estadual de Feira de Santana (UEFS), mestrado em Literatura Iberoamericana pela Universidad de los Andes (ULA-Venezuela), mestrado e doutorado em Teoria da Literatura e Literatura Comparada pela Universitat Autònoma de Barcelona (UAB-Espanha). Tem experiência como docente em diversas instituições de ensino superior, com ênfase em Línguas Estrangeiras Modernas, ministrando aulas de literatura, língua espanhola e estudos comparados. Coordena o Grupo de Teatro La Barraca formado por estudantes da UNEB e da comunidade externa desde que foi fundado em 2010 como uma atividade extensionista. Atualmente é Professor Adjunto do Colegiado de Licenciatura em Letras com Espanhol da Universidade do Estado da Bahia (UNEB)), Campus V.
} 
J.F.S. Filho Imágenes míticas y oníricas: un análisis desde la psicología arquetipal

\section{Psicologia arquetipal}

Vamos desde luego, a fin de ubicar mejor sus características centrales, declarar que la psicología arquetipal (o imaginal) no se trata de una nueva ciencia que, basada en postulados científicos, ha descubierto algo nuevo. Esa corriente nació a partir de la psicología analítica de C.G. Jung, principalmente de la visión de arquetipo de su creador, bien como del pensamiento de Henry Corbin y su Mundus Imaginalis ${ }^{2}$.

La palabra "Imaginal" la tomó James Hillman, uno de los fundadores de la psicología arquetipal, del pensador Corbin quien la usa para diferenciar de "imaginario" ya que este término está asociado a la idea de algo irreal. Ese último considera que la imaginación tiene no sólo una función reproductiva, sino además productiva y que este reino de imágenes (Mundus Imaginalis) se percibe solo por la imaginación creadora y no lo aprehendemos por el intelecto, ni por los sentidos.

Por lo tanto, esta escuela psicoanalítica al nombrarse "arquetipal" ya denota la deuda que tiene con la teoría junguiana de los arquetipos, que eran originalmente mitos, como subraya Hillman:

Mi trabajo se encamina hacia una psicología del alma basada en una psicología de la imagen. Estoy sugiriendo una base poética de la mente y una psicología que no arranca de la fisiología del cerebro, ni de la estructura del lenguaje, ni de la organización de la sociedad, ni del análisis de la conducta, sino de los procesos de la imaginación. Al invocar a Jung en el punto de partida, estoy reconociendo la importantísima deuda que la psicología de los arquetipos ha contraído de él (1999a, p. 41).

Como una disciplina del campo de la psicología, se dedica a estudiar la psique, que para los griegos era un mito que representaba la personificación del alma. Respecto a la relación entre psicología y mitos Hillman señala: "La mitología es una psicología de la antigüedad, la psicología es una mitología de la modernidad. Los antiguos no tenían propiamente una psicología, pero si tenían los mitos, los cuentos que especulaban sobre los humanos en relación con fuerzas e imágenes sobrehumanas" (HILLMAN, 2004, p. 4344). Así podemos considerar que el mito y la psicología juegan un papel semejante: colocar nuestras almas en conexión con otras dimensiones del ser humano.

2 Hillman adopta el término Imaginal, que significa reino del alma o de las imágenes a partir de la obra del islamólogo Henry Corbin, conforme su libro "Mundos Imaginalis, or the Imaginary and the Imaginal", Spring 1972, pp. 1-19. 
J.F.S. Filho Imágenes míticas y oníricas: un análisis desde la psicología arquetipal

Tal vez uno de los puntos más discutidos de esta corriente es que James Hillman rescata la idea de anima mundi ${ }^{3}$, o sea, el mundo y todo que existe contiene un alma. Cada ente existente posee una fisionomía estética, sea el individuo o un objeto, y será esta propiedad particular la que posibilita no sólo la interpretación, sino además activa la imaginación. Por tanto, para la psicología arquetipal el alma sería algo así como el significado que cada ente manifiesta al mundo través de su imagen. Al principio nos parece incompatible la idea de imagen como manifestación del alma del mundo con un trabajo de cuño científico. Sin embargo, como lo afirma Ítalo Calvino, entre pensamientos aparentemente contrarios hay conexión: “al leer el libro científico más técnico o el libro de filosofía más abstracto se puede encontrar una frase que inesperadamente sirva de estímulo a la fantasía figurativa" (CALVINO, 1990, p. 103).

Sólo el hecho de usar el vocablo "alma", ya podría poner en duda su credibilidad, cómo si ciertas palabras estuviesen prohibidas en el campo de los estudios serios. No obstante, en un intento por profundizar su significado, tomaremos una iniciativa arriesgada al usar la palabra "alma” en el sentido dado por la psicología arquetipal. En ese análisis veremos por ejemplo que no denota la noción religiosa de la parte inmaterial del ser humano que pasa a vivir tras su muerte. La idea no es que tenemos un alma, un cuerpo celestial, sino que somos un alma, y ello cambia nuestro enfoque completamente. Hillman expone que el alma no es una sustancia, sino una perspectiva, no es una cosa, sino una visión de las cosas y que antes se usaba este término, intercambiándolo con ánima del latín y psique del griego. Así que, este psicoanalista señala tres diferencias importantes a la hora de reflexionar sobre esa cuestión

En primer lugar, "alma" hace referencia a la transformación, por ahondamiento, de los acontecimientos en experiencias; en segundo lugar, la significación que el alma hace posible, tanto en lo que atañe al amor como en la inquietud religiosa, procede de su especial relación con la mиerte. Y en tercer lugar, por "alma" quiero entender las posibilidades de imaginación presentes en nuestra naturaleza, la experiencia a través de la especulación reflexiva, el sueño, la imagen y la fantasía, esa modalidad

3 J. Hillman dedica sobre esta cuestión un capítulo de su libro El pensamiento del corazón y apunta: "En lugar de la tradicional noción de la realidad física, basada en sujetos privados sensitivos y en objetos públicos inanimados, quiero proponer una visión característica de muchas culturas (llamadas primitivas y animistas por lo antropólogos culturales occidentales), que también tuvo su breve momento de auge en la nuestra a través de Florencia y de Marsilio Ficino. Me refiero al alma universal del platonismo, que no es otra cosa que el mundo dotado de alma. (...) Imaginemos más bien el anima mundi como una chispa, esa imagen credora que se presenta en su forma visible a través de las cosas" (HILLMAN,1999b, p.147). 
J.F.S. Filho Imágenes míticas y oníricas: un análisis desde la psicología arquetipal

que reconoce toda realidad como primordialmente simbólica o metafórica (HILLMAN, 1999a, p. 39-40).

Nos interesará en particular en el análisis sobre las imágenes míticas y oníricas justamente el tercer aspecto de su cita ("posibilidades de imaginación presentes en nuestra naturaleza”). Será por el hecho de poseer este alma - una parte intermedia entre el cuerpo (físico) y el espíritu (metafísico) ${ }^{4}-$, en el cual funciona la imaginación simbólica, que no solo los hombres de la antigüedad manifestaron un mundo mítico, sino además la raza humana siempre ha estado envuelta en un mundo de imágenes.

Como es sabido, para Jung la psique no solo es alma, sino además la imaginación, cuestiones que Hillman va a profundizar en sus estudios. Según este norteamericano, el alma implica el acto de percibir las cosas poéticamente, encontrando su fisionomía oculta. Es un proceso de apertura en el cual más que formar, se "deforman" las imágenes, como lo ve concienzudamente Gaston Bachelard: "Queremos siempre que la imaginación sea la facultad de formar imágenes. Y es más bien la facultad de deformar las imágenes suministradas por la percepción y, sobre todo, la facultad de librarnos de las imágenes primeras, de cambiar las imágenes" (BACHELARD, 1955, p. 19).

\section{Imágenes míticas}

Podríamos haber elegido cualquier otro enfoque para desarrollar nuestro estudio sobre las imágenes míticas ya este tema está presente en diversos campos de estudios científicos $^{5}$. Sin embargo, la psicología profunda postjunguiana de Hillman tiene la ventaja de no ver los mitos como algo muerto y enterrado en el pasado de la humanidad, ni como mero objeto pasivo de análisis, tampoco lo busca en su relación con factores externos como la historia, el lenguaje, la cultura -aunque puede servirse de la contribución de estos estudios.

4 En el mundo clásico el hombre se constituía de cuerpo (materia), alma (psíquico) y espíritu (metafísico) y solo a partir de Descartes (1596-1650) se establece una visión binaria de cuerpo-alma a través de su teoría "pienso, luego existo". Esta reducción en la forma de concebir el hombre en el Occidente hay afectado su dimensión trascendental y limitado sus potencialidades.

5 Peñuelas señala: "El misterio que rodea al mito se pierde en el pozo del pasado y en el de la naturaleza humana. Tal vez por eso parece haber ejercido siempre en el hombre irresistible fascinación. Y a intentar desentrañarlo se han dedicado competentes historiadores, filósofos, filólogos, poetas y, últimamente, antropólogos y sicólogos" (1965, p. 22). 
J.F.S. Filho Imágenes míticas y oníricas: un análisis desde la psicología arquetipal

La psicología arquetipal busca dentro del propio hombre entender el significado de los mitos y las razones de su existencia puesto que es un fenómeno que tiene como morada el alma de la humanidad. Diferente de la idea que suele darse a sus orígenes, el mito no nace de dudas de la mente humana, sino de imágenes simbólicas que arrebataron su espíritu, como señala E. Cassirer: "el genuino mito no empieza ahí donde la intuición del universo toma la forma de imágenes determinadas, de figuras de demonios y dioses, sino ahí donde se atribuye a estas figuras un nacimiento, un devenir y una vida en el tiempo" (CASSIRER, 1995, p. 141). También corrobora Marcelino C. Peñuelas que el mito "Surge de forma espontánea. No ha existido, ni existe, ningún grupo humano donde los mitos hayan dejado de aparecer y proliferar con vigorosa abundancia; porque, al fin y al cabo, responde a humanas necesidades" (PEÑUELAS, 1965, p. 16).

Otra descripción estereotipada que se suelen dar a los mitos es que tratan de historias con referencias explícitas a dioses, sin embargo, como advierte G. S. Kirk (1973), gran experto y estudioso del pensamiento griego, hay famosos héroes que ejercen un papel principal en los mitos griegos y que no son, de hecho, dioses, como Edipo y Perseo, donde la narración hace referencia a un hombre que transita entre seres humanos. Tras citar a autores que expresaron esta visión reduccionista en sus textos, el profesor Kirk apunta que: "Es una virtud de los eruditos clásicos la de que no son tan propensos a hacer esta clase de generalizaciones, al menos en su forma más simple; sin duda porque los héroes, que juegan tan gran papel en los mitos griegos, no son, obviamente, dioses” (KIRK, 1973, p. 24-25).

Una tendencia también común en la aproximación al estudio de las imágenes míticas es aquella que les otorga la acepción de "fábulas" y narraciones "inventadas". La teoría alegórica al respecto del mito la encontramos en Platón y tiene diversos seguidores hasta nuestros días, los cuales consideran ideas abstractas a un fenómeno que transciende a un entendimiento lógico. Sin embargo, hay autores que discrepan de esa teoría como ocurre al Xvarnah persa que ha estudiado Henry Corbin.

Toda interpretación racionalista equivocaría aquí el camino de reducir esta figura a una alegoría, con el pretexto de que 'personifica' el acto y el actuar del hombre. Pero dicha figura no es una construcción alegórica, sino una imagen primordial gracias a la cual es percibido un mundo de realidades que no es ni el mundo de los sentidos ni el mundo de las abstracciones del entendimiento (CORBIN, 2000, p. 49). 
J.F.S. Filho Imágenes míticas y oníricas: un análisis desde la psicología arquetipal

Esta explicación anterior se ajusta a nuestro análisis de los mitos ya que éstos igualmente no son un producto de los sentidos, ni de las abstracciones, sino que se manifestaron en el hombre de los preludios. Estamos hablando de una época donde el mundo no era comprendido, sino vivido y las experiencias no se basaban en el pensamiento, sino en la contemplación. En aquel entonces se consideraban los relatos míticos como una verdad ${ }^{6}$ que ocurrió en la antigüedad, momento en el cual a través de ellos el origen del mundo y la formación del hombre lograban un valor significativo. Concretamente, Mircea Eliade habla del in illo tempore cuando el mito tenía un valor sagrado y, por ende, era elevado al nivel de verdad. Por lo tanto la idea de "pasado" que suele asociarse a los mitos corresponde a una explicación simplista una vez que aquel comportamiento aún subsiste hoy día bajo otras formas. Al hablar de la diferencia entre el tratamiento que se daba al mito en el siglo XIX y en el siglo posterior, escribió M. Eliade (1991, p. 7):

En vez de tratar, como sus predecesores, el mito en la acepción usual del término, es decir, en cuanto 'fábula', 'invención', 'ficción', le han aceptado tal como le comprendían las sociedades arcaicas, en las que el mito designa, por el contrario, una 'historia verdadera', y lo que es más, una historia de inapreciable valor, porque es sagrada, ejemplar y significativa.

El hombre de la prehistoria atribuía un origen mítico a todo, por tanto veía las cosas con una mirada personificada. La existencia de la tierra era la prueba que existió el mito cosmogónico (cuando las cosas han sido creadas), bien como el mito del origen de la muerte se comprobaba a través de la mortalidad del ser humano (cuando la muerte pasó a existir), por lo tanto era el Mundo que confirmaba y daba veracidad a los mitos.

Más recientemente, los dioses y sus energías destructivas y re-creadoras se han convertido en meras referencias poéticas y al perder la cosmovisión del mundo, nos hemos apartado de un mundo en que convivían dioses, semidioses, hombre y naturaleza. Hemos perdido el vínculo que nos ligaba a otras formas de vida y a un mundo simbólico. Joseph Campbell advierte que "cuando las formas de los ritos y símbolos se difunden a otras zonas,

6 La fe a respecto de la existencia de estos seres era algo sagrado e indudable como señala Jacob Burckhardt: "No sólo estaba muy extendida la creencia de que los dioses y los hombres eran de la misma raza, sino que toda una serie de familias y de personalidades aisladas se enorgullecían de su ascendencia de dioses y héroes, y hasta creían poder enumerar, por lo menos, las generaciones intermedias" (BURCKHARDT,1964, p. 61). 
J.F.S. Filho Imágenes míticas y oníricas: un análisis desde la psicología arquetipal

o pasan a generaciones posteriores que ya no participan en la experiencia original, pierden profundidad, sentido, alma" (CAMPBELL, 1999, p. 118).

James Hillman propone justamente cultivar el "alma" que habita en todas las cosas del mundo y no rescatarla solo en términos conceptuales. Este investigador postjunguiano advierte que lo que plantea no es "revivir una fe muerta, porque no nos conciernen ni la fe, ni la vida o la muerte de Dios. Psicológicamente, los dioses nunca mueren; y la preocupación de la psicología arquetípica no es el renacimiento de la religión, sino la supervivencia del alma" (HILLMAN, 1999a, p. 338).

Con su psicología arquetipal, ese psicólogo estadounidense habla de una conciencia mítica del hombre primitivo cuando veía las cosas existentes como entidades personificadas. Todos los seres, animados o inanimados, poseían vida y valores sagrados, por ende, no había barrera entre yo-otro y sujeto-objeto ${ }^{7}$. En un estudio sobre la idea de alma en la Grecia Antigua Jan N. Bremmer apunta:

Si comparamos el alma animal con el alma humana descubriremos que para los griegos antiguos las dos almas tenían mucho en común; la ausencia del noos y la ausencia de cualquier mención de una psiqué que se dirige al Hades constituyen las diferencias más notables entre ambas. [...] La psiqué se menciona sólo una vez en Homero. Eumeo mata un cerdo para Odisea, y Homero escribe: 'La psiqué lo abandonó (14.426). Sin embargo, no se hace mención de que esta psiqué se dirigiera al Hades. Teniendo en cuenta que dicha mención tampoco se hace siempre en el caso de la psiqué humana, su ausencia aquí no se traduce necesariamente como incredulidad; simplemente no lo sabemos (BREMMER, 2002, p. 92).

Aunque había la conciencia de lo diferente, la manera de relacionarse con el mundo no era marcada por la idea de oposición, sino de continuidad, es decir, había una cosmovisión donde hombre y dios, vida y muerte, sueño y realidad eran elementos complementares. La cosmovisión mítica no concebía el mundo bajo la distinción entre las partes y el todo, ya que la unidad era parte de la totalidad, y a su vez ésta se formaba a partir de las unidades menores.

En nuestra era lo que prevalece es la idea de que solo existe lo que puede ser comprobado científicamente, aquello que pueda ser examinado y sometido al pensamiento

7 Sobre esta cuestión, Hillman ha expuesto: “Tendríamos que prescindir de juegos del tipo sujetoobjeto, izquierda-derecha, interior-exterior, masculino-femenino, inmanencia-trascendencia, mentecuerpo...en definitiva, del juego de los contrarios. Gran parte de aquello que nos es más querido tendría que venirse abajo para que la emoción contenida en estas preciadas reliquias pudiera romper esos recipientes y fluir de nuevo hacia el mundo" (1999b, p. 186). 
J.F.S. Filho Imágenes míticas y oníricas: un análisis desde la psicología arquetipal

racional. Todo debe ser definido, palpable y explicable, lo que elimina el misterio que había en la mentalidad del hombre antiguo. Existe una tendencia en el campo de las ideas y de muchas ciencias a hacer hincapié en las diferencias y en las oposiciones binarias del tipo: padres/hijos, amor/odio, blanco/negro, hombre/mujer. Sobre la idea de superioridad de lo masculino sobre lo femenino - pensamiento que ha reforzado y manipulado por muchas teorías a lo largo de la historia- expone el escritor postjunguiano:

La transformación de nuestra visión del mundo necesita la transformación de la visión de lo femenino. (...) esta transformación en lo que respecta a lo femenino no se refiere meramente a los derechos de la mujer, a la píldora o al matrimonio de los sacerdotes, sino a un movimiento de la conciencia en lo tocante al hombre corpóreo, a su materialidad y a su naturaleza instintiva. La imagen unitaria del mundo en metafísica requiere la previa unidad de sí en psicología, la conjunción del espíritu y la materia representada por lo masculino y lo femenino (HILLMAN, 2000, p. 246247).

Por esa vía algunas veces olvidamos que en estos binomios existe más conexión que exclusión; es decir que, aunque uno posea una luz propia, también forma parte de la misma constelación de los parentescos (padre-hijos), de los sentimientos (amor-odio), de los colores (blanco-negro), del ser humano (hombre-mujer). Incluso cuando hablamos de la oposición entre la conciencia mítica y la conciencia científica, esto debe ser relativizado $^{8}$. Aunque una utiliza la imaginación y otra la razón, ambas aspiran a un objetivo común: encontrar respuestas a cuestiones relacionadas al hombre y a su vida. Sobre las oposiciones Henry Corbin (2000) apunta que había magos primitivos que abogaban la idea de que hay un principio único para la luz y para las tinieblas, los cuales rechazaban el dualismo radical defendido por otros.

Esta concepción moderna de mundo que se basa más en las diferencias que en las semejanzas, nos conlleva a una visión fragmentada de la existencia. Vivimos sometidos a un universo de (pre)conceptos que priorizan la jerarquía, las fronteras, la separación, lo

8 Gillo Dorfles reflexiona que: "El arte podrá ser mito en las épocas en que el pensamiento mítico sea preponderante y podrá, en cierto sentido, ser 'ciencia' en épocas tecnológicas como la nuestra. Y no sólo como la nuestra: piénsese si no en otros ejemplos remotos de un arte que ha sido racionalidad pura y se ha acercado a la ciencia, como el arte de las pirámides, o ciertas formas de arte religioso, astronómico, hindú, babilónico, azteca. Esos monumentos que -cubiertos por la pátina del tiempo- estamos dispuestos a 'ver' hoy solamente como artísticos (en todo caso entretejidos con mitos), fueron, en realidad, instrumentos racionales y 'científicos' de un pensamiento, para aquellas épocas, sumamente maduro; y quizá fueron entendidos en aquel entonces más como documentos científicos -o al menos científico-iniciáticos- que como documentos artísticos" (DORFLES, 1969, p. 65). 
J.F.S. Filho Imágenes míticas y oníricas: un análisis desde la psicología arquetipal

que nos distancia cada vez más del otro y de aquella mentalidad del hombre antiguo donde todo estaba enlazado. E. Cassirer declara que en el pensamiento prehistórico había la relación mágico-simpática, la cual supone la idea de que existe un nexo entre una parte y su todo aunque ambos estén separados físicamente y como ejemplo agrega: "Los cabellos que un hombre se ha cortado, sus uñas o excrementos deben ser enterrados o quemados a fin de que no caigan en manos de un hechicero enemigo" (CASSIRER, 1972, p. 79). Esta visión antigua la cual consideraba que la parte de un cuerpo del hombre llevaba en su interior elementos vitales de la persona, ya traía una sabiduría que la ciencia vino a comprobar a posteriori con los estudios del ADN. Hoy en día a través de una gota de sangre se puede conocer además del perfil biológico de un individuo, sus rasgos psicológicos, es decir, somos un gran paquete y una parte divisible está orgánicamente unida a la totalidad.

Al hablar de los mitos, por tanto, nos adentramos en un mundo donde el alma no sólo habitaba en el cielo, sino además en la tierra y en todo lo existente. Si tomamos como ejemplo otras culturas, como la prehispánica, podemos encontrar que el maíz existía no solamente con la función de saciar al hombre del hambre, sino que simbolizaba un alimento sagrado. Eliade comenta que hay actos humanos “...que no están vinculados a su magnitud física bruta, sino a la calidad que les da el ser reproducción de un acto primordial, repetición de un ejemplar mítico. La nutrición no es una simple operación fisiológica; renueva una comunión" (ELIADE, 1972, p. 15). Para aquellos pueblos andinos antiguos el dios de la vegetación creó a los seres humanos y les puso a la disposición el maíz para mantenerlos. Así como para los antiguos nórdicos los truenos no eran un fenómeno de descarga eléctrica que tiene origen en los relámpagos, sino que eran el sonido producido por el martillo mágico del dios Thor.

Aunque los mitos se han convertido, como hemos visto, en alegorías, ficción e invención, y que hemos dejado de hablar con ellos, esto no significa que hayan dejado de existir, o hayan quedado mudos. En el momento que buscamos formas de comunicación con aquel mundo mágico podemos restablecer un tipo de diálogo. Por supuesto que no será lo mismo que hacían aquellos individuos, ya que el mundo ha cambiado y la conciencia del hombre moderno se diferencia de la antigua. De ahí que Hillman afirme que para devolver la perspectiva mítica hace falta despertar la capacidad de personificación de nuestra alma: 
J.F.S. Filho Imágenes míticas y oníricas: un análisis desde la psicología arquetipal

Al desechar los argumentos habituales en contra de la personificación, esperamos encontrar una nueva forma o perfeccionar una ya existente de revitalizar nuestras relaciones con el mundo que nos rodea, de conocer nuestra fragmentación individual, nuestros múltiples espacios y voces, y de fomentar la imaginación para descubrir sus aspectos brillantes (HILLMAN, 1999a, p. 58-59).

En nuestra época, la conciencia moderna nos ha des-almado ${ }^{9}$ y tan sólo a unos se les permiten habitar este mundo imaginal: a los niños, a los locos y a los artistas. Sin embargo, el mundo real no llena nuestra alma y la necesidad de viajar por el reino de la imaginación sigue viva en nuestro ser, así que aún se consultan a tarotistas y videntes, se endiosan a los dioses de la música y del cine, se recurren a la literatura y otras formas de expresión artística para tener una experiencia con lo simbólico. Una de las posibilidades de reencantar nuestra mirada es volver los ojos a los mitos, que llenaban de luz y sentido la existencia humana.

\section{Imágenes oníricas}

En los estudios de la psicología arquetipal, el sueño adquiere una valiosa importancia para desentrañar el misterio del alma (psique), puesto que en él se abren las puertas de la imaginación, además de poder mirarnos a nosotros mismos como un gran espejo que refleja nuestra propia imagen.

Al relacionar las imágenes oníricas con los mitos, podemos afirmar que los últimos no han sido creados por la imaginación de aquellos hombres del pasado, sino que les ocurrió como pasa con las criaturas que surgen en nuestros sueños espontáneamente. Hay seres que aparecen cuando estamos dormidos los cuales nunca los hemos visto en el mundo de la vigilia y, no obstante, durante esta experiencia onírica éstos no son considerados irreales. Podemos sentir sus presencias y hablarles sin cuestionar su existencia. Del mismo modo para las sociedades antiguas, que tenían una conciencia mítica, los seres míticos eran criaturas reales, con la diferencia de que podían sentirlos y comunicarse con ellos despiertos. Hillman menciona:

9 Apunta Hillman: "Las intenciones, conductas, voces o sentimientos que yo no puedo controlar con mi voluntad o conectar con mi razón son extraños, negativos, psicopatológicos. (...) Tanto el mundo de allá fuera como el de aquí dentro han sufrido el mismo proceso de despersonificación. Nos han des-almado a todos" (1999a, p. 58). 
J.F.S. Filho Imágenes míticas y oníricas: un análisis desde la psicología arquetipal

De la misma manera que no creamos nuestros sueños, sino que nos ocurren, así tampoco inventamos a las personas del mito y de la religión; ellas también nos ocurren. Las personas son anteriores a cualquier esfuerzo nuestro por personificar. Para la conciencia mítica, las personas de la imaginación son reales (HILLMAN, 1999a, p. 82).

Ya Peñuelas señala que para el psicoanálisis el origen del mito está relacionado con las actividades del inconsciente humano y añade: "Así parece pensar Jung cuando habla del 'inconsciente colectivo', al tratar de su teoría de los arquetipos que relaciona íntimamente con la raíz del mito. Y al parecer por influencia de sus ideas es corriente hoy considerar el mito como un 'sueño colectivo"” (PEÑUELAS, 1965, p. 43).

El pensamiento mítico tiene como génesis el soñar colectivo de raza humana del pasado que, en su esencia, aun se manifiesta en el hombre contemporáneo cuando entra en contacto con formas de la imaginación creadora. A través del sueño nos asemejamos a los hombres de todas las épocas, puesto que es una capacidad común a todo individuo. Es una actividad central del alma que se manifiesta naturalmente, es decir, no es algo que producimos, sino más bien que nos invade y en lo cual no podemos elegir estar o no dentro. No son las imágenes oníricas que están en nosotros, sino nosotros que estamos y somos esas imágenes, así que a lo mejor es el propio sueño que nos elige a nosotros mismos ya que es éste quien decide cuál papel vamos a actuar y que tipo de historia vamos a vivir en el escenario onírico.

Al hablar de los sueños en un trabajo que pretende hacer un análisis de las imágenes oníricas, recurrir a una cita del consagrado libro de Freud La interpretación de los sueños es una tendencia natural. "Sospechamos cuán acertada es la opinión de Nietzsche de que 'el sueño continúa un estado primitivo de la humanidad, al que apenas podemos llegar por camino directo' y esperamos que el análisis de los sueños nos conduzca al conocimiento de la herencia arcaica del hombre" (FREUD, 1977, p. 543). Esta obra fue publicada en la transición del siglo XIX al XX y sus reflexiones pasaron a ser una referencia casi obligatoria en los trabajos que tratan de un tema tan complejo como este. James Hillman recuerda que el creador del psicoanálisis, a pesar de considerar que los sueños no tienen vínculo explícito con el mundo ${ }^{10}$, intenta darle una interpretación (como el propio título nos indica) pero fuera del ámbito nocturno donde ocurrieron: “el sueño pertenece

10 Hillman aclara qué: "Por mundo diurno y la luz diurna no quiero entender el mundo cotidiano, sino la visión literal de cualquier mundo en el cual las cosas parecen ser tal como se nos presentan, y no hemos profundizado en su lado oscuro, su sombra nocturna" (2004, p. 28). 
J.F.S. Filho Imágenes míticas y oníricas: un análisis desde la psicología arquetipal

totalmente al ámbito del dormir, la interpretación de los sueños consiste en traerlos de nuevo al mundo diurno, o sea, rescatar o reformar el sueño (según la propia metáfora de Freud) de su locura submundanal y de su inmersión en el principio del placer" (HILLMAN, 2004, p. 25).

No solo esta visión freudiana es distinta a la que plantea el psicoanalista arquetipal, sino además a la de los junguianos por dos aspectos: hacer consciente lo inconsciente y por la traducción terapéutica de los sueños al lenguaje de la vida de la vigilia. Aunque se opone a la idea de que el sueño necesita ser traducido al lenguaje de la vigilia, el psicoanalista arquetipal reconoce la importancia del pensamiento de los dos y dialoga con sus ideas: "A lo largo de mi tesis seguiré a Freud y a Jung, aunque no solamente a ellos: a Freud cuando insiste en que el sueño no tiene nada que ver con el mundo de la vigilia, sino que es la psique hablándose a sí misma en su propio lenguaje, y a Jung cuando insiste en que el ego tiene que ajustarse al mundo nocturno" (HILLMAN, 2004, p. 27-28).

No es el propósito de este trabajo entablar un debate sobre las diferentes posturas adoptadas por estos estudiosos del psicoanálisis, sino más bien buscar en esta disciplina que estudia el alma humana elementos que la vincule al mundo míticos y de los sueños. Así como en una obra teatral tan sólo podemos llegar a una lectura, en el mundo de los sueños jamás alcanzaremos una interpretación que abarque todos sus sentidos subyacentes. Freud también apunta que en los sueños existe una zona obscura y desconocida que nos lleva a varios puntos, como una especie de ombligo del desconocido: "Los pensamientos oníricos con que nos topamos a raíz de la interpretación tienen que permanecer sin clausura alguna y desbordar en todas las direcciones dentro de la enmarañada red de nuestro mundo de pensamientos" (FREUD, 1991, p. 519).

$\mathrm{Al}$ aproximar las imágenes oníricas con el fenómeno teatral, podemos reconocer que el sueño se compone de escenas que eliminan el tiempo cronológico y la singularidad espacial, el teatro se hace de sueños y también nos pone en contacto con otras realidades y otro tiempo. Tanto el soñador como el espectador viven una experiencia abierta a todas las posibilidades, no tienen poder de elegir el rumbo de las historias, pueden hacer parte de las mismas como observador o partícipe (teatro interactivo) y sienten emociones que nacen a partir del contacto con la imaginación. Por lo tanto, el teatro y el sueño tratan de fenómenos que nos conducen a un mundo imaginal. Hillman aclara que cuando soñamos no solamente las personas, sino además uno mismo va a desempeñar un papel conforme las necesidades escenificadas por el sueño: 
J.F.S. Filho Imágenes míticas y oníricas: un análisis desde la psicología arquetipal

...estamos viendo y actuando en una película, en una ópera o en la puesta en escena de una novela histórica, una representación espectacular. En el teatro de nuestros sueños, tú y yo, aunque estemos entre el público, estamos en el escenario: todos somos actores, todos somos personajes oníricos, llevando la máscara apropiada según el personaje que debemos representar y la forma en que lo debemos representar (HILLMAN, 2004, p. 147).

Como hemos visto, el psicoanalista postjunguiano insiste en que los sueños deben ser observados desde la escena donde se desarrollan y no debemos "trasladarlos" a la conciencia despierta ya que esta última posee otros criterios y códigos que simplifican su mundo de complejidades profundas. El mundo diurno tiene leyes que se diferencian de las del mundo onírico, puesto que en éste podemos por ejemplo volar como pájaros, actuar libremente sin juicio de valores morales y olvidar ideas maniqueas. Hillman añade que en los sueños “....nada puede ser referido de nuevo a lo superior, no hay retorno hacia arriba. No hay buenas o malas perspectivas en los sueños, porque la esperanza es una categoría extraña e irrelevante en el inframundo, donde cada sueño es a fin de cuentas un deseo autosatisfecho" (HILLMAN, 2004, p. 153-154).

En los estudios sobre las imágenes oníricas, se suele buscar una conexión entre éstos y la vida, en cambio, Hillman traza un recorrido contrario ya que en su teoría el mundo de los sueños está vinculado a la muerte ${ }^{11}$. El hombre no es únicamente mortal, sino además un ser soñante y a través del soñar logra entrar en contacto con otra realidad, la cual se puede ver con los ojos cerrados como si estuviera sin vida. Esta dimensión puede ser comparada al reino de los muertos, o la Casa de Hades (si quisiéramos darle un valor mitológico) o de la oscuridad (si volvemos a una tradición literaria).

En el soñar ocurre una muerte iniciática puesto que se borran los límites de tiempoespacio y se abren las puertas de la percepción hacia formas sobrenaturales y habitantes solo en ese mundo. Del mismo modo como los sueños para Freud estaban asociados a la idea de represión, y para Jung a la de compensación, en Hillman y la psicología arquetipal sería como una iniciación.

Nuestra época suele estar tildada como la era de la imagen, pero no de la imaginación en el sentido que plantea James Hillman, puesto que este exceso de formas

11 "El trabajo deformativo y transformador de los sueños constituye la Casa de Hades, la muerte individual de cada uno. Cada sueño se erige a partir de esta casa, y cada sueño es un ejercicio de entrada al inframundo, una preparación de la psique para la muerte" (HILLMAN, 2004, 187). 
visuales tiene únicamente como meta el entretenimiento. Su psicología arquetipal habla de un ejercicio que implica no sólo adentrar, sino además ser adentrado por las imágenes míticas y oníricas, restaurando la capacidad de conectar con lo más profundo de nuestra alma.

\section{Referências}

BACHELARD, G. El aire y los sueños: ensayo sobre la imaginación del movimiento. México: Fondo de Cultura Económica, 1955.

BREMMER, J. N. El concepto del alma en la antigua Grecia. Madrid: Ediciones Siruela, 2002.

BURCKHARDT, J. Historia de la cultura griega. v. 1. Barcelona: Iberia, 1964.

CALVINO, I. Seis propuestas para el próximo milenio. Madrid: Siruela, 1990.

CAMPBELL, J. Las máscaras de dios: mitología creativa. Madrid: Alianza Editorial, 1999.

CASSIRER, E. Filosofía de las formas simbólicas II (el pensamiento mítico). México: FCE, 1995.

Filosofía de las formas simbólicas - Pensamiento Mítico. México: F.C.E., 1972.

CORBIN, H. El hombre de luz en el sufismo iranio. Madrid: Edciones Siruela, 2000.

DORFLES, G. Nuevos ritos, nuevos mitos. Barcelona: Lumen, 1969.

ELIADE, M. Mito y realidad. Barcelona: Labor, 1991.

El mito del eterno retorno. Madrid: Alianza, 1972.

FREUD. S. La interpretación de los sueños. Buenos Aires: Círculo de lectores, 1977.

. "El olvido de los sueños". In: Obras Completas. v. 5. Buenos Aires: Amorrortu Editores, 1991.

HILLMAN, J. El sueño y el inframundo. Barcelona: Paidós, 2004.

Re-imaginar la psicología. Madrid: Ediciones Siruela, 1999a.

El pensamiento del corazón. Madrid: Siruela, 1999b.

El mito del análisis. Madrid: Ediciones Ciruela, 2000.

KIRK, G.S. El mito su significado y funciones en las distintas culturas. Barcelona: Barral, 1973.

PEÑUELAS, M. C. Mito, literatura y realidad. Madrid: Gredos, 1965. 
J.F.S. Filho Imágenes míticas y oníricas: un análisis desde la psicología arquetipal

Artigo recebido em: 09.03.2021

Artigo aceito para publicar em: 12.05.2021 